Final article in:

Hingley, M.K., Leek, S., and Lindgreen, A. (2008), "Business relationships the Morrissey way”, British Food Journal, Vol. 110, No. 1, pp. 128-143. (ISSN 0007-070X)

For full article, please contact LindgreenA@cardiff.ac.uk

\title{
Business Relationships the Morrissey Way
}

\author{
Martin Hingley, ${ }^{1,2}$ Harper Adams University College \\ Sheena Leek, ${ }^{3}$ Birmingham Business School \\ Adam Lindgreen, ${ }^{4}$ Hull University Business School
}

\footnotetext{
${ }^{1}$ Dr. Martin Hingley, School of Management, Harper Adams University College, Newport, Shropshire, TF10 8NB, United Kingdom. E-mail: mhingley@ harper-adams.ac.uk. Telephone + 441952815386.

${ }^{2}$ The authors contributed equally and have been listed alphabetically.

${ }^{3}$ Dr. Sheena Leek, Birmingham, Birmingham Business School, University House, Birmingham, B15 2TT, United Kingdom. E-mail: s.h.leek@bham.ac.uk. Telephone: + 441214146226.

${ }^{4}$ For all correspondence: Professor, dr. Adam Lindgreen, Department of Marketing and Business Strategy, Hull University Business School, Hull, HU6 7RX, United Kingdom. Email: A.Lindgreen@hull.ac.uk. Telephone: + 441482463010.
} 


\section{Interpersonal Business-to-Business Relationships the Morrissey Way}

\section{Research paper}

Purpose - This paper uses the novel approach of drawing on song lyrics, which concern interpersonal relationships, and applies these to an interpersonal business-to-business relationship context.

Design/methodology/approach - Interpretation is made by utilising the song lyrics of the prolific English singer Morrissey as a template for interpersonal relationship structures that can be applied to interpersonal business-to-business relationships.

Findings - Highlighted are findings from recent case investigations into business-to-business relationships where the 'human factor' is particularly important in maintaining business interaction. The findings show that concepts key to business-to-business relationships (the need to enter relationships, power and dependency, and relationship break-up) are not always in the realms of corporate rational thinking. Alternatively, business decisions owe much to the less rational and more emotional world of interpersonal relations.

Research limitations - This paper is a combination of both theoretical and practical study, but is only a starting point in terms of necessary empiricism. The paper concludes with suggestions of further necessary empirical investigation.

Practical implications - Practical lessons include challenge to the view that there is 'right' and correct formula to engage in business relationships and route to relationship success. 
Practical reality and human nature determine that even incrementally successful relationships can break-down and gains can be quickly reversed.

Originality/value of the paper - This paper takes the important theme of business relationships and underpins it with a novel treatment: the use of song lyrics, in order to highlight that prior and somewhat formulaic templates for business success are not always appropriate; and business relationships are governed by a human factor that is not always positive in outlook.

Keywords - business interpersonal relationships; food industry; human factor; power; Morrissey. 


\section{Introduction}

The creation of 'value' is essential in marketing (Anderson and Narus, 1999; Doyle, 2000). Indeed, the role of marketing is "to assist the firm to create value for its customers that is superior to competition" (Tzokas and Saren, 1999: 53). If this takes place, Lindgreen and Wynstra (2005) write, the firm can arguably deliver superior value to its shareholders. This is important because customers, who are satisfied with a firm's goods or services that offer them value, ceteris paribus, remain loyal to that firm and place their future purchases with that firm. Perhaps surprising then is that firms often do not know how to define value, or how to measure it (Anderson and Narus, 1998). In fact, there has been only little research examining what value is, "[despite] its importance for the marketing discipline, little research effort has been devoted to examining what this value is, how it is produced, delivered and consumed and how it is perceived by the customer" (Tzokas and Saren, 1999: 53).

The argument underlying the interest in the concept of 'relationship' is that buyers and suppliers do not only do business with each other because of the value of the good or service being exchanged (Lindgreen and Wynstra, 2005). There may be factors on the level of the supplier firm that make one offer more attractive than another one, including for example the reputation or location of the supplier, but also the supplier's innovative capability. Even if this

capability is not reflected in the characteristics of the current offering it may be 'valuable' to set up a relation with this supplier, as it makes it less likely that for example the buyer firm needs to change suppliers in the future when it requires new or other goods or services. Hence, one can speak of a value of a relationship for certain offerings that are above and beyond the actual product or service being exchanged (Lindgreen and Wynstra, 2005). 
In order to understand the nature of business-to-business relationships, practitioners, analysts, and academic theorists have drawn heavily on the context and literature of social exchange theory; with useful origins to be found in literature on social psychology and the study of human interpersonal relations. Much has been written about how interpersonal relationships develop, and subsequent authors have placed this into a context of business interaction and development. For example, Hinde (1979, in a study of personal relationships, believes that dyadic relationships can never be fully understood in isolation from their social context. Thibaut and Kelly (1959) view the process of human bonding as a continuum of sampling, bargaining, commitment, and institutionalisation. Hinde (1979) sees that the participants in relationships change with time through natural processes of growth, development, and decay. These views pre-empt business-to-business exchange being described in terms of interaction and progression. An often used analogy, for example, of business relationship forming is that of marriage (Harker, 2002; Tynan, 1997).

Subsequently, social exchange literature has been used as a basis for business-to-business relationships and context for business exchange in evolving frameworks. The human and social context has emerged in studies of customer relationships (Bagozzi, 1975) and in business-to-business relationships, where social factors are seen as a requirement for success (Pole and Haskell, 2002; Sheth and Sharma 1997). Halinen and Salmi (2001), in investigating the importance of personal relations in the development of business-to-business relationships, believe, however, that the significance of this has been ignored, stating that personal relations should be at the heart of business contacts. The 'human factor' inherent in interpersonal relationships should, therefore, be a central plank of relational exchange in dyadic and wider business-to-business networks. 
The above is neatly illustrated by Blois (1998) who contends that it is people who make decisions and not organisations. In a similar vein, Cahill (1998) states that relationships are conducted between people and not, as is so often described, with products. The people factor is very much evident in empirical studies conducted which investigate its influence on business relationships. This is evidenced, for example, in the work of Hingley (2001) and White (2000) concerning relationships between food industry suppliers and their powerful retail customers in which the 'good' terms of their ongoing interaction is a determining factor in relationship success. These studies also illustrate that the nature of the personality (particularly of buyers) and suppliers' reaction to that personality is similarly important.

The majority of studies concern the understanding and application of human relationships and social theory to a business relationship context. However, there has been further treatment of issues concerning issues of power and business relationships (e.g., Cox, 2004; Hingley, 2005; Kumar, 1996; Kumar et al., 1998). Less is written about what the result of such evolution of power imbalance actually means to practitioners, and how this may affect future action.

\section{Research Methodology}

The purpose of this study is to investigate the 'human factor' inherent in business-to-business relationships and its impact on the key phases of business relationships: (a) relationship attraction and initiation, (b) relationship development, and (c) relationship dissolution.

The paper draws on existing literature sources relating to these principal phases in order to identify the impact of the human factor with the process. Specifically, findings from prior studies of business-to-business buyer-seller relationships in the agri-food and food retailing 
channels are utilised (Hingley, 2001, 2005; Gedeon, 2006; White, 2000). These food industry relationship studies provide useful context in that they are typified by the importance of people in regular and ongoing exchange, and are conducted in an environment of fierce retailer-driven channel rationalisation, which exposes issues of power and dependency.

There is a further, novel approach to the study of the above process in the paper. The study draws on the song lyrics of Stephen Patrick Morrissey who was born May 22, 1959, in Manchester, England; 'a shy, awkward youth'. He met guitarist Johnny Marr in 1982 and the two began writing songs together as the pivotal relationship in the highly successful band The Smiths (Online biography, 2006). Morrissey, a prolific songwriter, is renowned for his heartfelt and emotional treatise on personal and human relationships, which is expressed in a poetic style. He has a back-catalogue of published songs with The Smiths, and, following their break-up at the end of that decade, has enjoyed continuing success as a solo artist to this present day. What is particularly attractive to chroniclers of human emotions and interactions is the depth and breadth of the material covered. Morrissey's lyrics are literate and poetic, 'filled with romantic angst, social alienation, and cutting wit'. Morrissey, however, has always faced criticism 'for his self-absorption and determinedly miserable outlook' (Online biography, 2006).

Morrissey is by no means unique in his lyrical treatment of his subject, but his body of work is large and consistent in the treatment of pertinent themes that warrant investigation and justify interpretation in a wider context. Whilst much of popular song concerns issues of love and break-up, the work of Morrissey is (somewhat uniquely) further reaching, especially in consideration of the more negative aspects of interpersonal relationships and those that concern human frailty, selfishness, even petulance. It is this broad umbrella of negative 
relationships that make the work interesting. Correspondingly, there is a gap in application of interpersonal relationships to a business-to-business context, especially in consideration of these more negative factors. Theory surrounding the atmosphere of industrial buying tends to focus on interaction between positive and proactive participants. However, industrial buyers are by no means entirely rational, nor immune to 'negativity'. It is, therefore, interesting to view business relationships from the alternative perspective raised in this unusual context.

The approach was to conduct historical/archival research as a form of case study method (Yin, 2003). Full transcripts of song lyrics (of over 200 songs) are available (from internet sources) and these were systematically analysed. The songs were interpreted through content analysis, utilising a set of procedures to make valid inferences from text (Weber, 1985) and by identifying coherent and important examples, themes, and patterns in the data (Patton, 2002; Sayre, 2001). At the least, this material acts as a 'soundtrack' to pertinent issues of human attitudes regarding interpersonal circumstances. Further, the material has then been used to signpost issues concerning the nature of under-explored facets of human relationships, and exposes evolving typologies which facilitate relationship templates; and these are subsequently applied to the context of business interaction.

Preliminary investigation identifies some specific and consistent threads concerning relationships in the work of Morrissey and The Smiths that may have resonance with business relationships. Issues covered in the body of work spanning over 20 years concern matters of the need for relationships; exclusive relationships; the impact of power balance on relationship participants; relationship insecurity; relationship superficiality; and the lengths that parties will go to sustain relationships. 
These themes have not necessarily all been applied previously to a business-to-business relationship context. It is anticipated that outcomes may form the basis for application of a new perspective, which can provide a necessary interpretation to complement the existing body of work in this area, which has tended to focus on relationship progression as an inevitable and desirable process. The study of the nature of human relationships from the Morrissey perspective explores the viewpoint that relationships perpetuate, but are not in all cases positive, progressive, or mutually satisfying. There is a good deal of scope for the understanding of reasons behind the continued existence of 'negative' and even 'sick' relationships. The italicised lyrics form a basis of sub-structure to the areas of business interpersonal relationships to which they are applied (and the song titles are attributed in brackets and italicised).

In the song On the Streets I Ran Morrissey highlights the fact that he has used frailties of the human condition/ relationships as the basis of his art; in that he has 'Turned sickness into (un) popular song'. In echo of this, the paper endeavours to use the song lyrics as means of identifying and focusing on some of the under-explored human attitudes inherent in businessto-business relationships ('sick' or otherwise).

\section{Findings}

\section{Relationship Attraction and Initiation}

"I'm human and I need to be loved, just like everybody else does" (How Soon Is Now?)

"All I ask of you is one thing that you'll never do. Would you put your arms around me?" (Tomorrow) 
A pervasive theme of Morrissey's lyrics is unrequited love. He has an intense desire to be in a relationship and the intensity of this desire is expressed in many songs and lyrics, such as that encapsulated in the lyric from the song How Soon Is Now (above). In business, the initiation of relationships is an area, which has not come under sufficient scrutiny. In order for a relationship to be initiated one of the parties must be 'attracted' to another party. A significant amount of research has gone into determining what criteria buyers use to determine the 'attractiveness' of a supplier. For example, Lehmann and O'Shaughnessy (1982) identified 17 attributes, which were used to evaluate suppliers. These attributes related to price, ordering convenience, service, supplier technical capabilities and product operating characteristics, etc. Supplier reputation and personal relationships, that is the intangible aspects of the relationship, were also deemed to be important factors. In assessing potential customer relationships, suppliers will ask a number of questions such as what is the value or potential of the relationship, where in the company's portfolio will they be, what is the network position of the company, etc. (Ford et al., 2002). The supplier will also consider the customer's reputation and the processual aspects of the relationship. Organisations may be more able to assess the concrete abilities of companies, for example production capability, credit worthiness prior to approaching them than the intangible relationship aspects.

A gap in this rather practical approach, whereby suppliers' attributes and service capabilities are the determining factors of attraction, does not take into account significant market structural realignment in modern business practice. Migration of channel power downstream in most business markets, including the food industry, is such that it is often in the hands of near-market superpowers (retailers and distributors); and places the decision-making process of channel selection firmly in the hands of buyers. Added to this, a pervasive theme of 
rationalisation of supply bases by such buyers intensifies the competitiveness amongst suppliers for access to reduced market opportunities, and more market significant buyers; hence an increasing need for suppliers to be wanted (Bourlakis, 2001; Hingley, 2001, 2005). This too is can be a source of anxiety for them.

"You should never go to them. Let them come to you." (I Don't Owe You Anything)

Holmen et al. (2005) identified 11 ways in which relationships may begin. These were classified as either active or reactive methods. Active methods are ones, which the company initiates, for example the customer may initiate contact with a supplier. Reactive methods are ones where the company does not initiate contact, for example a customer may wait for suppliers to approach it. Although it is unlikely that any company will be totally active or totally reactive in terms of initiating relationships, it would be interesting to determine whether certain types of companies are more inclined to be active than reactive. For example, it might be expected that suppliers are more active than reactive. In the food industry, buyerled rationalisation and retailer market power have determined that the expectation is that suppliers will initiate (new supplier) contact and that retailers' need only wait. However, the drive to secure 'exclusive' supply has meant that retailers' have been keen to secure and 'ringfence' the best suppliers in each product category (Hingley, 2001).

Holmen et al. (2005) also stated that relationships were initiated either by direct contact or through a network. With the network-mediated approach it is clear that the person or company introducing one company to another knows both parties personally. Social relationships have been found to be important in the initiation of relationships (Dibben and Harris, 2001; Godar and O'Connor, 2001; Halinen and Salmi, 2001; Ruokolainen, 2005; 
Tesar and Moini, 2005). To illustrate, Dibben and Harris (2001) found relationships formed from pre-existing social relationships were more likely to be developed and renewed than those arising out of the need for exchange.

"I just want to be seen... Oh, in the back of your car." (You've Got Everything Now)

Business competition has to be understood from the perspective of networks. Hingley (2005) identifies competition in UK agri-food as, for example between the supply network led by Tesco versus that of J. Sainsbury, versus that of Asda. Profitability, therefore, relies on the competitive success of one network against another and, therefore, for a supplier of unbranded fresh foods being part of the branded retailer network is a source of kudos. There is the benefit of association with a big company (and its supply network). In the song You've Got Everything Now, Morrissey identifies the need of some to be identified with success. In food industry relationships, being part of a particular supermarket supply network was often also the key to further 'referral' business and therefore the seal of buyer approval (Hingley, 2005).

\section{Relationship Development}

"Hand in glove. The sun shines out of our behinds. No, it's not like any other love. This one is different - because it's us." (Hand in Glove)

"Hand in glove. We can go wherever we please, and everything depends upon how near you stand to me." (Hand in Glove) 
There is a general business trend for dominant channel members to practice discrimination in the type(s) of relationships that they have with different suppliers. For example, favoured partners may be tied-in to exclusive agreements, whilst others are kept on a more transactional footing. There are many examples of business-to-business relationships, where buyer organisations practice tiering or classification of suppliers in order to give higher proportions of business to preferred 'partners' (Christopher and Jüttner, 2000; Dorsch et al., 1998). This has given rise to key account management where there is an emphasis on those relationships in an organisation's portfolio that are most significant to their business (Harden, 2004). This reflects the process described in Dorsch et al. (1998) as the stratification of vendors by buyers (e.g., as best, good, or poor). This inevitably leads to supply channel rationalisation, such that buyers may focus on fewer, but exclusive suppliers to their businesses, facilitated by 'close to the customer' and 'partnership' ideals. To succeed, these types of relationships require large degrees of ongoing communication and interaction between exchange partners and are often typified by a hothouse environment in order to add joint value through exclusive products and services (Hingley, 2001, 2005; White, 2000).

\section{"I won't share you, no." (I Won't Share You)}

"There never need be longing in your eyes, as long as the hand that rocks the cradle is mine." (The Hand that Rocks the Cradle is Mine)

However, in the food industry there is a trend for powerful buyers to hold best suppliers close and ideally not let them trade with other competitors (Hingley, 2001), which means that such exclusivity arrangements can perpetuate a feeling of paranoia, driving buyers to continually reassert their supply chain authority, regularly stressing who it is that is driving the system, 
and that suppliers will continue to benefits and prosper so long (and only if) as buyer-driven exclusivity remains (Gedeon, 2006; Hingley, 2001).

You've got everything now (You've Got Everything Now)

The downside of exclusivity and reduced supply base arrangements (for suppliers) are in the limitations derived from the poor negotiating position of being tied-in to relationships with much more powerful organisations (Gedeon, 2006; Hingley, 2001). This may create an anxiety to please amongst suppliers for whom sales opportunities are reduced by the prevalence in business of the buyer-driven 'reduced source' model. Such changes in the business relationship landscape have precipitated a more competitive business era in which "We cannot cling to the old dreams anymore" (Still Ill) and, perhaps, a more unforgiving business age.

"I crack the whip, and you skip". (Handsome Devil)

Antecedence with respect to the role of power in relationships can be found in Thibaut and Kelly (1959) who explore the area of conflict and the issue of both coercive and constructive conflict in personal relationships. The balance between power and dependency is termed power asymmetry (Anderson and Weitz, 1992; Newman et al., 2004). However, Cox (2004) contends that power in business relationships is not a simplistic view of balance or imbalance leading to 'win-win' parity or 'win-lose' inequity, rather that power is demonstrated as a range of conditions inherent in business exchange. Levels of power are determined by the relative utility and relative scarcity of resources exchanged between the parties. Hence, there are degrees of power in the different circumstances of exchange, and this can change in a flux 
between parties, even within an ongoing relationship. A business organisation's response to the influence of power should, therefore, be appropriate to particular and changing circumstance (Cox, 2004). It is thus interesting to identify perceptions of businesses to changes in power status. Morrissey, in You've Got Everything Now, considers (from the perspective of others who have known him through the power transition from ordinary man to famous singer) how it is to have no power, then all the power:

"Back at the old, grey school, I would win and you would lose. You've got everything now". (You've Got Everything Now)

Business-to-business relationships are not static, things can change over time. Power symmetry is not a natural state in supply channels and networks, and organisations desire imbalance in order to gain the upper hand in exchange relationships. The balance of power may, therefore, alternate between exchange parties, as it is natural for each party to try to secure maximum gain for himself. In many business-to-business relationships there is an acceptance of power asymmetry and an overwhelming feeling of supplier pragmatism about this state of being.

"Within an hour the power could totally destroy me (or, it could save my life)." (Hairdresser on Fire)

Kumar (1996) contends that the vast majority of manufacturer-retailer relationships are imbalanced. This is an accurate description of the state of power in supply channels, where one party (increasingly the buyer/retailer) holds sway. A more extreme view is that relationships are inherently unstable, and are in danger of becoming fief-like, when suppliers 
are tied-in to powerful, dominant partners (Blois, 1997). This situation can bring tremendous, exclusivity derived rewards, and/or potential disaster to suppliers. The dangers of such asymmetrical relationships, where the power of the dominant, less committed and more opportunistic party disadvantages the weaker party have been noted (Anderson and Weitz, 1992; Johnsen and Ford, 2002). Powerful channel members can enforce punitive capabilities and actions (in response to the errors or failings of a partner) in which they can inflict negative consequences (Kumar et al., 1998). This is seen in the food industry cases where, for example, suppliers may try to break 'exclusivity' agreements and supply a retailer's competitor in order to gain extra business. This kind of action is often met with swift punitive action (Gedeon, 2006; Hingley, 2001). The ability and the capability of a partner to reciprocate punitive action depend upon the balance of power and dependency. A forerunner to this can be found in the study of interpersonal relations (Thibaut and Kelly, 1959) where both reward and coercive power are rooted in sanctions established in order to extract compliance.

Power asymmetry is, therefore, normally perceived to be a negative state (Newman et al., 2004). Business relationship literature, particularly that literature relating to conditions of interaction, seems to be most concerned with ideal conditions for exchange, balance, and even fairness. A further alternative view with regard to power is that which contends that presence of power imbalance does not mean that it is always explicitly exercised (Cox et al., 2001). This is clearly not always the case, as weaker partners do enter these relationships and tolerate power imbalance. Weaker parties in asymmetric relationships have a certain degree of tolerance to imbalance of power, and they are not necessarily unstable or short lasting (Blundel and Hingley, 2001; Narayandras and Rangan, 2004). 
Relationships are seldom fair in the division of power or reward, nor are all parties equally active in commitment to them (Gummesson, 1996; Kumar, 1996). It is not, therefore, surprising that benefits are, or seem to be, unequally shared. This does not mean, however, that such power-imbalanced exchanges are not workable or enduring. Business-to-business relationships can be aligned, even in circumstances of inequality or where there are tensions resulting from power imbalance (Cox, 2004). As well, mutuality of outcomes (with respect to profitability) is not commensurate with the nature of business relationships, meaning that 'win-win' outcomes are not an absolute but a variable concept (Cox, 2004); such that there are degrees of winning in respect of the division of rewards. Relationships are not perceived by all parties to the relationship in the same way. One person's perspective of a relationship may be very different to someone else's. This may be due to any number of factors on his own or interacting.

\section{"Vivid and in your prime, you will leave me behind." (These Things Take Time) "I'd leap in front of a flying bullet for you." (What Difference Does it Make?)}

In discussion of an interpersonal relationship, Morrissey feels that this person's qualities will naturally take the person away from him, the person is too good to stay with him, or the person does not realise how good he is and as soon as the person does he will go. Morrissey feels he is not good enough for the person:

“But I can't believe you'd ever care”. (These Things Take Time)

A consequence of power asymmetry in business-to-business relationships is insecurity, whereby weaker partners may feel that they are not good enough to be a relationship, or may 
be supplanted by an organisation with a better business proposition. Powerful buying organisations may benefit from this supplier insecurity in order to retain power. Weaker parties, conscious of the 'coldness' of the environment in which business exchange operates outside of prevailing 'exclusivity' arrangements, are eager to please their larger 'partner' customers in provision of high levels of service and initiative taking, and sometimes this may go beyond customer expectations, as suppliers know that in order to retain business the pressure is on to almost over-achieve. Further, lack of esteem by suppliers, who do not know their worth, may lead to further anxiety. In food industry relations both Gedeon (2006) and Hingley $(2001,2005)$ chronicle an almost desperate need for food suppliers to please their important customers.

In the seminal work by Morgan and Hunt (1994), business-to-business relationships are determined in the following way: "In healthy relationships partners acquiesce because of commitment to relationships rather than through the exercising of power as in sick relationships. Long run relationships are associated with the absence of coercive power and presence of trust and commitment”.

However, it is not always realistic to regard power-imbalanced relationships as 'sick'. Studies identify varying, degrees, and fluctuations in trust, commitment, and uses of power that do not necessarily impact upon the longevity and continuity of relationships. Relationships in business exchange are not always (and, in practice, unlikely) to be mutual in inputs and outputs, but this does not prevent relational exchange. There is a high degree of tolerance of weaker partners with respect to displays of power and in the acceptance of the inequity of outputs (resultant mutuality); power imbalance can be regarded as a 'normal' state of affairs (Batt, 2004). 
Power is understood by some commentators to be as constructive, coercive, co-operative, and competitive at the same time within dyadic relationships (Thibaut and Kelly, 1959; Kumar, 1996). Four types of power in business interactions: (a) dependence, (b), punitive capability, (c) non-coercive influence strategies, and (d) punitive actions have been identified (Kumar, 1996).

Kumar (1996) considers only punitive actions to constitute the antithesis of trust in relationships. Food industry case analysis (Gedeon, 2006; Hingley, 2001, 2005) reveals attitudes in line with Kumar's view concerning the presence of the first three power factors, and agree that such power imbalance under this definition is no barrier to entry or to relationship longevity. Whilst Kumar (1996) considers that only the fourth dimension of power, punitive actions, precludes business relationship, interestingly, both Hingley and Gedeon indicate that even punitive action by powerful food industry buyers does not prevent suppliers from wanting (perhaps needing) to continue to engage.

"Why do I give valuable time to people who don't care if I live or die?" (Heaven Knows I'm Miserable Now)

"Why do I smile at people who I'd much rather kick in the eye." (Heaven Knows I'm Miserable Now)

Another unexplored area of power and dependence is the issue of superficial compliance of weaker parties. For example, how much of a veneer of social niceties is there in business exchange, how bad do things have to get before this is stripped back? Weaker suppliers (as seen in the case studies by Gedeon and Hingley) will 'bend over backwards' to comply, but 
privately they may think otherwise. On one level in certain circumstances, businesses do have to perform tasks that do not please them. Alternatively, it could be that in some relationships where individuals and their organisations have no power they have to do things for people/companies who do not care about them or their organisation, but may have to because they are so crucial to the future success of business. In the supply-base rationalised food industry this is a particularly pertinent issue.

"I stole and I lied and why? Because you asked me to." (What Difference Does it Make?)

We have already identified that with reduced supply base and 'preferred' access to key customer accounts, supplier organisations are very keen to retain business. But do they want retain a relationship with another company so desperately they would do anything to achieve it? How far would organisations and would this even push at the bounds of legality? The food industry is a heavily regulated and has buyer led checks and controls in place that make the market highly 'traceable'. Cases illustrate how strict retailers are at enforcing (or having network intermediaries enforce on their behalf) quality and product/ingredient traceability systems for food (Gedeon, 2006). In one study, a case supplier organisation is put out of business when found to be in serious breach of food chain safety measures.

\section{Relationship Dissolution}

Research into the dissolution of relationships has tended to focus on the reasons for wishing to withdraw (Bitner, Booms, and Stanfield-Tetreault, 1990; Colgate and Hedge, 2001, Keaveney, 1995; Wendelin, 2002; Ulaga, 2003), modelling the course of relationship dissolution (Halinen and Tahtinen, 2002; Ping and Dwyer 1992), and on the strategies used by 
companies to disengage themselves (Alajoutsijarvi, Möller, and Tahtinen, 2000; Halinen and Tahtinen, 2002). There are various strategies for exiting a relationship. They can be divided into two broad categories: direct communication (informing the company that the relationship is ending) and indirect communication (where the desire to exit the relationship is not explicitly stated). The strategies used within these categories may also be divided into two categories: they may be self oriented (i.e., the company is concerned with itself at the other party's cost) and other oriented (i.e., the company wants to avoid hurting the other party).

A direct, self-oriented strategy would entail the company telling the other party directly the relationship is over with no opportunity for discussion, whereas a direct other-oriented strategy, the revocable exit, entails the company telling the other party, but being open to discussing the reasons. An indirect, self-oriented strategy - cost escalation - entails the company creating a negative atmosphere by increasing the price if it is the supplier or demanding extra services if it is the customer. An indirect, other-orientation - pseudo deescalation - entails the company informing the party the company is reducing the amount of investment in the relationship (Alajoutsijarvi, Möller, and Tahtinen, 2000).

The exit strategy a company chooses to use may depend on a number of factors, such as the length of the relationship, the atmosphere of the relationship (i.e., the degree of trust, commitment, cooperation, power, and dependence). In a long-term relationship, the company may choose a revocable exit. It may let the other party know it wants to end the relationship, but keep the lines of communication open so they can discuss problems and potentially maintain the relationship. In a short-term relationship, the company may just inform the other party the relationship is over without the opportunity to discuss it. The degree of power a company has could influence the exit strategy it uses. A powerful company may take a direct, 
self-oriented approach and inform the other party the relationship is over, whereas a less powerful company may take a pseudo de-escalation approach. It is important for the company to be aware of these potential signs, and to identify what is causing the other party to want to end the relationship.

"For we have been through hell and high tide I think I can rely on you. So what difference does it make? It makes none." (What Difference Does it Make?)

In power-imbalanced relationships, the decision to break-up can be enforced by the powerful party. In the food industry, notably, this has been as a result of the deliberate policy of supplybase rationalisation, particularly in fresh food commodity areas, where supply numbers are reduced to those usually larger and more efficient suppliers (Hingley, 2001, 2005, White, 2000). Of particular note in the case studies in Gedeon (2006) is that the decision by supermarkets to de-list suppliers can be brutal and happen regardless of past 'good' business exchange relations. The decision often takes place from a perspective of a purely economic context. The past and what has gone before does not count for anything. Companies may have gone through a lot together, but there may come a time in the search for better profit or improved differentiation that it does not count and buyers select and obtain a better supplier. All the trust, commitment etc that has been built up is worthless. However, suppliers in these cases also noted that negative experiences with individual buyer organisation personnel did have a part to play in their demise (Gedeon, 2006).

"I know it's over - still I cling, I don't know where else I can go" (I Know It's Over)

"Yes, I walk around-somehow, but you have killed me." (You Have Killed Me) 
Even in the face of inevitable loss of contract to supply, some organisations still desperately hang on to faint hope of reprieve. This is once again evident in food industry supplier-retailer dissolution cases (Gedeon, 2006). Time and again, de-listed suppliers will fight the inevitable and seek to be let back into the network, even though they have been clearly 'frozen-out' by powerful retail buyers. This reflects the extremely difficult situation food industry suppliers find themselves in when faced with rationalisation and where there are few options for future supply in a market held by few powerful customers.

\section{Conclusions and Recommendations}

The objective of this paper was to conduct a novel approach through the analysis of the treatment of interpersonal relationships in lyric form to provide a canvass for the identification of business relationship issues. These issues concern a well-trodden area (e.g., power-dependency), but highlight some new, or perhaps overlooked, aspects relating to the 'human dimension' inherent in business exchange. In supply-base rationalised markets such as food, the desire for relationships is intense. The critical factor behind this seems to be the growing lack of opportunities in mature markets for alternative ongoing sales outlets, other than those offered by networks/consumer markets controlled by a powerful few retail or distributive outlets. In the food industry, 'exclusivity' arrangements offer at the outset what appears to be guaranteed and ongoing market access, but this also constitutes a 'golden handcuff'. Suppliers to markets like the food industry are generally pragmatic about issues of supply chain power and the fact that its balance is held by their important retail customers. In this context, suppliers are accepting of expressions of power by their customers (and, of course, have no choice but to be so). However, interestingly, even punitive action does not prevent suppliers in this sector from wishing to continue the relationship. In fact, suppliers are 
often unable to accept the final reality of severed business relationships and will still be seeking a future window of opportunity to get back with a customer. Suppliers in imbalanced relationships (like food) are often insecure, lack esteem, and appear to compensate by overserving their customers. This may indeed be expressed on a superficial basis, but then also the true meaning of retailer-initiated 'close to the customer' and 'partnership' schemes may also be equally superficial. Food industry cases (e.g., Gedeon, 2006) show that past 'good' business relationships count for little when the necessity of cost driven rationalisation is driving, and with rationalisation the good goes out with the bad.

This paper highlights that human and interpersonal responses to business exchange issues, particularly those relating to power-dependency are not always rational and predictable; and that the unpredictable nature of human emotion often holds sway in supposedly rational business environments. Future research could concern whether food industry relationships, with their concentrated, mature, and hyper-competitive structures are typical of dyadic business relationships, and whether participants in other business-to-business exchange contacts act in similar ways. Areas for investigation in other business contexts should, therefore, focus on:

- The perceived need for relationship forming.

- The nature of exclusivity arrangements.

- The significance of network and channel rationalisation of relationship forming.

- The impact of punitive actions on business partners.

- The significance of quality of past relationships on future retention.

- The lengths to which people/ organisations will go to maintain relationships. 
An avenue for future exploration (in the context of business relationships) may be to investigate the influence of place, local culture, and attitudes on relationship formation and development. In current vogue are issues of food industry networks of local supply. But is there a 'human dimension' to this that remains un-researched? It may be particularly interesting, therefore, to compare geographic areas which display differing local and regional personality traits; and analyse (perhaps stereotypical) characteristics of such regions and the influence upon business relationship formation. After all Morrissey is forever associated with Manchester, England (as his birthplace and well of inspiration for some of his more ferocious bile against the world and the concerns of his interpersonal relationships). Should, therefore, 'place', the characteristics of place, and the personalities of individuals shaped by their location and upbringing not be a determining factor in their business network relationships?

\section{References}

Alajoutsijarvi, K., Möller, K., and Tahtinen, J., (2000), "Beautiful exit: how to leave your business partner”, European Journal of Marketing, Vol. 34, No. 11/12, pp. 1270-1290.

Anderson, E. and Weitz. B. A. (1992), "The use of pledges to build and sustain commitment in distribution channels", Journal of Marketing Research, Vol. 29, February, pp.18-34.

Anderson, J. C. and Narus, J. A. (1998), "Business marketing: understand what customers value", Harvard Business Review, Vol. 76, No. 6, pp. 53-65.

Anderson, J. C. \& Narus, J. A. (1999), Business Market Management: Understanding, Creating, and Delivering Value, Prentice Hall, Upper Saddle River, NJ.

Bagozzi, R. P. (1975), "Marketing as exchange", Journal of Marketing, Vol. 39, No. 4, pp. $32-39$. 
Batt, P. J. (2004), "Power-dependence in agricultural supply chains: fact or fallacy?" in the Proceedings of 20th Annual Conference of the Industrial Marketing and Purchasing Group, Copenhagen, 2-4 September.

Bitner, M. J., Booms, B. H., and Stanfield-Tetreault, M., (1990), “The service encounter: diagnosing favourable and unfavourable incidents", Journal of Marketing, Vol. 54, No. 1, pp. 71-84.

Blois, K. J. (1997), “Are business-to-business relationships inherently unstable?” Journal of Marketing Management, Vol. 13, No. 5, pp. 367-382.

Blois, K. J. (1998), “Don’t all firms have relationships?” Journal of Business \& Industrial Marketing, Vol. 13, No. 3, pp. 256-270.

Blundel, R. K. and Hingley, M. K. (2001), "Exploring growth in vertical inter-firm relationships: small-medium firms supplying multiple food retailers”, Journal of Small Business and Enterprise Development, Vol. 8, No. 3, pp. 245-265.

Bourlakis, M. A. (2001), "Future issues in European supply chain management", in Eastham, J. F., Sharples, L., and Ball, S. D. (2001), Food Supply Chain Management: Issues for the Hospitality and Retail Sectors, Butterworth-Heinemann, Oxford, pp. 297-303.

Cahill, D. J. (1998), "Relationship marketing? But all I really wanted was a one-night stand”, Marketing News, Vol. 32, No. 19, p. 4.

Christopher, M. and Jüttner, U. (2000), “Supply chain relationships: making the transition to closer integration", International Journal of Logistics: Research and Applications, Vol. 3, No.1, pp. 6-23.

Colgate, M. and Hedge, R. (2001), “An investigation into the switching process in retail banking services”, International Journal of Bank Marketing, Vol. 19, No. 5, pp. 201-212.

Cox, A. (2004), “The art of the possible: relationship management in power regimes and supply chains", Supply Chain Management, Vol. 9, No. 5, pp. 346-356. 
Cox, A., Sanderson, J., Watson, G., and Lonsdale, C. (2001), "Power regimes: a strategic perspective on the management of business-to-business relationships in supply networks, in the Proceedings of the 17th Annual Conference of the Industrial Marketing and Purchasing Group, Oslo, 9-11 September.

Dibben, M. R. and Harris, S. (2001), "Social relationships as a precursor to international business exchange", in the Proceedings of the 17th Annual Conference of the Industrial Marketing and Purchasing Group, Oslo, 9-11 September.

Dorsch, M. J., Swanson, S. R., and Kelly, S. W. (1998), “The role of relationship quality in the stratification of vendors as perceived by customers”, Academy of Marketing Science, Vol. 26, No. 2, pp. 128-142.

Doyle, P. (2000), Value-Based Marketing: Marketing Strategies for Corporate Growth and Shareholder Value, John Wiley \& Sons, Chichester.

Ford, D., Berthon, P., Brown, S., Gadde, L.-E., Håkansson, H., Naude, P., Ritter, T., and Snehota, I. (2002), The Business Marketing Course: Managing in Complex Networks, John Wiley \& Sons, Chichester.

Gedeon, I. (2006), Relationship Dissolution in U.K. Supermarket Supply Chains, unpublished $\mathrm{PhD}$, University of London.

Godar, S. H. and O’Connor, P. J., (2001), "Same time next year - buyer trade show motives", Industrial Marketing Management, Vol. 30, No. 1, pp. 77-86.

Gummesson, E. (1996), "Relationship marketing and the imaginary organisation: a synthesis”, European Journal of Marketing, Vol. 30, No. 2, pp. 31-44.

Harden, G. (2004), "Now, tell me one more time... just how useful is RM? Exploring whether relationship marketing can play a useful role in transactions between a UK business school and its corporate clients", in the Proceedings of the Academy of Marketing Annual Conference, Cheltenham, July. 
Halinen, A. and Tahtinen, J. (2002), “A process theory of relationship ending”, International Journal of Service Management, Vol. 13, No. 2, pp. 163-180.

Halinen, A. and Salmi, A. (2001), "Managing the informal side of business interaction: personal contacts in the critical phases of business relationships", in the Proceedings of the 17th Annual Conference of the Industrial Marketing and Purchasing Group, Oslo, 9-11 September.

Harker, M. J. (2002), "Lingua franca: customer relationship metaphor and anthropromorphism", in the Proceedings of the Academy of Marketing Annual Conference, Nottingham, July.

Hinde, R. A. (1979), Towards Understanding Relationships, Academic Press, London.

Hingley, M. (2001), "Relationship management in the supply chain”, International Journal of Logistics Management, Vol. 12, No. 2, pp. 57-71.

Hingley, M. (2005), "Power to all our friends? Learning to live with imbalance in UK supplier-retailer relationships”, Industrial Marketing Management, Vol. 34, No. 8, pp. 848858.

Holmen, E., Roos, K., Kallevag, M., von Raesfeld, A., de Boer Luitzen, and Pedersen, A.-C., (2005), “How do relationships begin?", in the Proceedings of the 21st Annual Conference of the Industrial Marketing and Purchasing Group, Rotterdam, 1-3 September.

Johnsen, R. E., and Ford, D. (2002), "Developing the concept of asymmetrical and symmetrical relationships: linking relationship characteristics and firms' capabilities and strategies", in the Proceedings from the 18th Annual Conference of the Industrial Marketing and Purchasing Group, Dijon, 5-7 September.

Keaveney, S. M., (1995), “Customer switching behaviour in service industries: an exploratory study”, Journal of Marketing, Vol. 59, No. 2, pp.71-82. 
Kumar, N. (1996), “The power of trust in manufacturer-retailer relationships", Harvard Business Review, November-December, pp. 92-106.

Kumar, N., Scheer, L. K., and Steenkamp, J.-B. E. M. (1998), "Interdependence, punitive capability, and the reciprocation of punitive actions in channel relationships", Journal of Marketing Research, Vol. 35, May, pp. 225-235.

Lehmann, D. R. and O'Shaughnessy, J. (1982), "Decision criteria used in buying different categories of products", Journal of Purchasing and Materials Management, Vol. 59, No. 1, pp. 62-72.

Lindgreen, A. and Wynstra, F. (2005), "Value in business markets: What do we know? Where are we going?" Industrial Marketing Management, Vol. 34, No. 7, pp. 732-748.

Morgan, R. M., and Hunt, S. D. (1994), "The commitment-trust theory of relationship marketing", Journal of Marketing, Vol. 58, No. 3, pp. 20-38.

Narayandras, D. and Rangan, V. K. (2004) "Building and sustaining buyer-seller relationships in mature industrial markets", Journal of Marketing, Vol. 68, No. 3 pp. 63-67.

Newman, A., Lings, I., and Lee, N. (2004), "What's in a handshake? Exploring business-tobusiness relational exchange", in the Proceedings of the Academy of Marketing Annual Conference, Cheltenham, July.

Online Biography (2006), http://www.vh1.com/artists/az/morrissey/bio.jhtml (accessed June 12, 2006).

Patton, M. Q. (2002), Qualitative Research and Evaluation Methods, 3rd ed., Sage Publications, Thousand Oaks, CA.

Ping, R. and Dwyer, F. R., (1992), "A preliminary model of relationship termination in marketing channels", in Frazier G.L. (Ed.), Advances in Distribution Channel Research, Vol. 1, JAI Press, Greenwich, CT, pp. 215-33 
Pole, K. L. and Haskell, J. (2002), "Managing a modern relationship: critical factors for business to business markets", in the Proceedings of the Academy of Marketing Annual Conference, Nottingham, July.

Ruokolainen, J. (2005), "Key concepts for building customer references - creation of a domain model for start up technology companies, in the Proceedings of the 21st Annual Conference of the Industrial Marketing and Purchasing Group, Rotterdam, 1-3 September.

Sayre, S. (2001), Qualitative Methods for Marketplace Research, Sage Publications, Thousand Oaks, CA.

Sheth, J. and Sharma, A. (1997), "Supplier relationships: emerging issues and challenges", Industrial Marketing Management, Vol. 26, No. 2, pp. 91-100.

Tesar, G. and Moini, H. (2005), "Duality in technology transfer networks: case of the federal government and the private sector", Proceedings of the 21st Annual Conference of the Industrial Marketing and Purchasing Group, Rotterdam, 1-3 September.

Thibaut, J. W. and Kelly, H. H. (1959), The Social Psychology of Groups, Wiley \& Sons, New York, NY.

Tynan, C. (1997) “A review of the marriage analogy in relationship marketing”, Journal of Marketing Management, Vol. 13, No. 7, pp. 695-703.

Tzokas, N. and Saren, M. (1999), "Value transformation in relationship marketing", Australasian Marketing Journal, Vol. 7, No. 1, pp. 52-62.

Ulaga, W. (2003), "Capturing value creation in business relationships: a customer perspective", Industrial Marketing Management, Vol. 32, No. 8, pp. 677-693.

Weber, R. P. (1985), Basic Content Analysis Series: Quantitative Applications in the social sciences, 49, Sage Publications Inc. Beverly Hills, Calif. 
Wendelin, R. (2002), "Bond episodes: a catalyst of the weakening and strengthening of bonds? Cases from the truck producing industry", 2nd Nordic Workshop on Relationship Dissolution.

White, H. M. F. (2000), "Buyer-supplier relationships in the UK fresh produce industry", British Food Journal, Vol. 102, No. 1, pp. 6-17.

Yin, R. K. (2003), Applications of Case Study Research, 3rd ed., Sage Publications, Thousand Oaks, CA.

\section{Web sites accessed}

http://www.sing365.com/music/lyric.nsf/The-Smiths-

lyrics/8A34A238E2075E534825699D002AF1AD

http://www.lyricsfreak.com/m/morrissey/96060.html

http://www.vh1.com/artists/az/morrissey/bio.jhtml 


\section{Biographies}

Dr. Martin Hingley is a Principal Lecturer in Marketing, based at Harper Adams University College in Shropshire, the leading university in the UK specializing in agri-business. His primary research interests are in marketing and in the applied areas of food industry marketing and supply chain relationship management. He has presented and published widely in these areas, and serves on the editorial boards of several academic journals.

Sheena Leek is currently a Lecturer in Marketing at the Birmingham Business School. Her current research interests are interpersonal contact within business-to-business relationships and the impact of information technology and the use of social capital to enter networks. Her work has been published in Industrial Marketing Management, Journal of Customer Behaviour, and Journal of Marketing Management.

Dr. Adam Lindgreen is Professor of Strategic Marketing at Hull University Business School. Adam Lindgreen has published in several journals including Industrial Marketing Management, Journal of Business Ethics, Journal of Business and Industrial Marketing, Business Horizons, Journal of Marketing Management, and Psychology \& Marketing, among others. His research interests include business and industrial marketing, consumer behavior, experiential marketing, relationship and value management, and corporate social responsibility. He serves on the board of many journals including Industrial Marketing Management and Journal of Business Ethics. 